\title{
Entrepreneurship and Economic Growth: Does Entrepreneurship Bolster Economic Expansion in Africa?
}

\section{Omoruyi EMM ${ }^{1 *}$, Olamide $\mathrm{KS}^{2}$, Gomolemo $\mathrm{G}^{3}$ and Donath $\mathrm{OA}^{4}$}

${ }^{1}$ Institute of African Studies, Zhejiang Normal University, China

${ }^{2}$ Marketing, College of Economics and Management, Zhejiang Normal University, China

3/nternational Trade, College of Economics and Management, Zhejiang Normal University, China

${ }^{4}$ Human Resource Management, College of Economics and Management, Zhejiang Normal University, China

*Corresponding author: Dr Mitchell Omoruyi EM, Institute of African Studies, Zhejiang Normal University, China, Tel: +234-802-354-5408; E-mail: mmacroe@yahoo.com

Rec date: July 21, 2017; Acc date: September 13, 2017; Pub date: September 20, 2017

Copyright: (c) 2017 Omoruyi EMM, et al. This is an open-access article distributed under the terms of the Creative Commons Attribution License, which permits unrestricted use, distribution, and reproduction in any medium, provided the original author and source are credited.

\begin{abstract}
Entrepreneurship, with its focus on opportunities, is often seen as one of the cornerstones of poverty alleviation in sub-Saharan Africa (SSA). One of the key objectives of modern economics is to determine factors that influence the economic development. This paper, therefore, seeks to discuss entrepreneurship as one of the factors that influence the economy of a nation, either directly or indirectly. It is a fact that entrepreneurship plays a significant part in shaping the landscape of a country's economy. Economists and policy makers recognize this fact. In fact, entrepreneurship is the engine of economic growth and it has come to be perceived as a catalytic agent for expansion and promotion of productive activities in every sphere of economic life all over the world. This research will focus on finding out how entrepreneurship influences the economy of sub-Saharan Africa. The main objective of this paper is to show the significant effect of entrepreneur towards economic prosperity. The paper argues that entrepreneur is positively correlated to economic growth than foreign aid. The paper shows that entrepreneurship positively explains the variations in the growth of African countries. It is, thus, reasonable to contend that entrepreneurship in developing economies including Africa even if replicative is instrumental to unlocking economic growth, create employment and reduce poverty. The paper further examines some of the challenges faced by entrepreneurs in sub-Saharan Africa and provide some policy recommendations.
\end{abstract}

Keywords: Africa; Aid; Entrepreneurship; Employment; Poverty reduction; Economic growth

\section{Introduction}

Entrepreneurship is generally described as the ability of an individual or a group of individuals to create or discover an opportunity and utilize it to the benefit of the society, which, in turn, will bring success to the innovators and their organization. According to Dau and Cuervo-Cazurra [1], the authors take a legalistic view of entrepreneurship and define it 'as the creation of fresh businesses a stable collection of people who coordinate their efforts to produce fresh value-added economic activity'. The relationship between entrepreneurship and economic growth of a country has increasingly gained a lot of interest from economists and policy makers over the years. However, while some view it as a direct relationship, others see it as an indirect kind of relationship. According to Sarkar [2], this interest has been fuelled by the desire to understand how entrepreneurship influences the economy of a country. Both the economists and policy makers recognize the effect of entrepreneurship on the economy of a country. In fact, entrepreneurship has been considered as the engine of economic growth and it has come to be perceived as a catalytic agent for expansion and promotion of productive activities in every sphere of economic life all over the world. The role and significance of entrepreneurship development in numerous nations worldwide were quite significant. Numerous countries leaders and scholars have proposed that entrepreneurship can be a panacea for empowerment, job creation, economic transformation, and poverty reduction., particularly in Africa. For the past decades, numerous nations in developed and developing nations have moved their policies from being directed towards a managed economy to an entrepreneurial economy. In addition, entrepreneurship largely contributes to proper utilization of resources, the establishment of a developed self-sufficient society, and creation of employment opportunities.

The role of entrepreneurship in economic development through job creation has turned out to be a priority for numerous nations against the provision of foreign aid. Speaking of foreign aid, despite the trillions of dollars of aid allocated to African nations, Africa still experiences a constant upward shift in poverty line over two decades. It calls for various international agencies and governments of other nations to embark on strategies to alleviate the scourge of poverty and promote Africa's economy. In the 1960s most of the Sub-Saharan African countries came out of colonization, hence being influenced to adopt a state-led centrally planned economic structure since they gained independence. Meanwhile, most developed economies in the recent time adopted a different model for their economic growth and development in absolute poverty reduction and employment creation. Africa is witnessing what is referred to as "youth bulge", or a population dominated by young people. Governments of these African nations should be aware of the significance of making the best advantage of this young population, otherwise, it will be turned into a burden particularly in the prevailing soaring unemployment trend among most of the African nations. Youth unemployment is a problem that affects most countries, especially in Africa Okafor as cited in 
Adebayo [3]. The capability of youth to engage in productive activities has both social and economic consequences in the society. There are almost 1.2 billion people aged between 15 and 24 years in the world. Out of these 200 million are in Africa, and out of these about 75 million are looking for work; this represents about 20 percent of the world's population [4]. According to the ILO (Ibid), Africa has the fastest growing and most youthful population in the world hence the biggest workforce. Over 40 percent of this population is under the age of 15 . Specifically, it is estimated that by 2050 , the youth will constitute 18.6 percent of the population in Central Africa, 18.5 percent in Eastern Africa, 18.8 percent in Western Africa, 15.6 percent in Southern Africa, and 13.9 percent in North Africa ILO (Ibid). Nearly 300 million people in sub-Saharan Africa are aged between 10 and 24 years, and these figures are anticipated to soar to around 561 million by the middle of this century (ILO (Ibid).

To find a solution to this young population and judging from the levels of unemployment in Africa, employment creation that specifically centres on promoting the entrepreneurial sector in the economy becomes vital. Since the 1980s, small business owners and entrepreneurs have been receiving greater recognition as drivers of economic growth. Recently, several studies $[5,6]$ have reported that long-term economic growth and prosperity require participation from entrepreneurs. Both experts and governmental authorities opt for fostering entrepreneurship as an appropriate mechanism to face the impacts of the economic crisis' [7]. Over the last two decades, the extensive literature on the importance of small businesses in the economy has consistently shown that the creation of new businesses drives economic prosperity. Also, playing a crucial role in increasing the competition of emerging sectors, new small businesses are critical to economic growth and innovative capacity in many regions. Job creation, economic growth and poverty reduction are usually the main political interests in entrepreneurship; entrepreneurship is therefore a driving force within the economy, particularly due to entrepreneurs' innovative nature.

Moreover, the fact about entrepreneurship and what it can do to bolster African economy remain inevitable that is why entrepreneurship is identified as an important driver of employment creation in African economies. Entrepreneurship boosts economic growth by introducing innovative technologies, products, and services. Increased competition from entrepreneurs' challenges existing firms to become more competitive. It also provides new job opportunities in the short and long term. Entrepreneurial activity raises the productivity of firms and economies. They also accelerate structural change by replacing established, sclerotic firms and this is what is really needed for the economic growth of Sub-Saharan Africa. The rest of the paper is structured as follows: Section 2 looks at the literature review on entrepreneurship as a catalyst for economic prosperity. Section three analyses entrepreneurship, unemployment and poverty reduction in a close relationship; section four looks at the obstacles faced by the entrepreneur in Sub-Saharan Africa countries and business development services challenges; section five concludes the paper with some possible recommendations.

\section{Literature Review}

The literature review section consists of two parts: the entrepreneurship-growth relationship and the determinants of economic growth.

\section{Entrepreneurship-growth relationship}

According to Audretsch et al. [8], the authors assert that the significant contribution of entrepreneurship to economic growth lies in its serving as a medium for the spill over of knowledge that might otherwise have stayed un-commercialized. However, empirical evidence on the relationship between entrepreneurship and economic growth is conflicting. According to Van Stel et al. [9], the authors assert that while entrepreneurship has a positive correlation with per capita GDP growth in wealthy countries, its relationship with growth in poor countries is negative. In another study, Reynolds et al., [10] mentioned that there is a negative correlation between real per capita GDP among all countries and the entrepreneurial activity. Also, some other authors find the similar outcome in their studies [11-13]. According to Baumol [14], the author juxtaposes entrepreneurship against the hackneyed prescription of Keynesian theory that in times of economic downturn augmented government spending should be the panacea. Furthermore, Baumol [14] asserts that abundantly projects entrepreneurship can act as an alternative means of stimulating growth 'that may hold greater appeal for today's policy makers and global leaders'.

According to Jiang et al. [15] survey, the authors discovered that an upsurge in the number of entrepreneurs generates a growth-improving variety effect and that diminished overall quality of entrepreneurial ability undermines economic growth. Evidence from West Germany indicates that entrepreneurship positively impacts growth. Audretsch et al. [16] report from West Germany that innovation efforts have an indirect effect on economic performance through entrepreneurship and that knowledge-based entrepreneurship positively explain regional economic performance. Mueller [17] tests the hypothesis that entrepreneurship and university-industry relations promoted economic growth in West German regions between 1992 and 2002 and reports that regions with a prominent level of entrepreneurship and university-industry relationships record greater productivity, and consequently, economic growth. Both start-ups in innovative industries and university research in engineering science are found to advance economic growth. Mueller [18] tests whether entrepreneurship is an important medium for knowledge flows and economic growth for the West German regions between 1990 and 2002 and finds that a rise in innovative start-up activity is more effective than an increase in general entrepreneurship in accelerating economic growth.

In another study, Stefanescu [19] examines the correlation between economic development and entrepreneurial activity in the European context. The groups of nations as defined by the Global Entrepreneurship Monitor employed for the survey are efficiencydriven nations such as Turkey, Latvia, Croatia, Hungary, and Romania; and innovation-driven nations such as Switzerland, Greece, Norway, Slovenia, Germany, Belgium, Italy, United Kingdom, Ireland, Finland, Denmark, France, Portugal, Spain, Netherlands, Sweden, and Iceland. The survey discovers that nations with diverse economic development level are distributed based on their entrepreneurial activity during the international crisis. Harbi et al. [20] explore the causal relationship between entrepreneurship and economic growth with data (19962007) from 34 OECD countries and report that there is a unidirectional causality running from entrepreneurship to economic growth. The results also suggest that increases in self-employment promote economic growth over the short term but reduce economic growth in the long-term horizon.

According to Galindoa and Mendez [21], the authors examine whether feedback effects exist among entrepreneurship, economic 
growth and innovation employing statistics from thirteen developed nations. The authors discover proof in support of feedback effects: economic activity supports entrepreneurship and innovation activities. The authors discover that innovation activities give backing to economic activity as well. It seems there is some cloud of scepticism surrounding the significance of entrepreneurship to economic growth in developing nations. This is because, in most developing nations where production takes place well within the technological frontier, economic growth is not 'innovation-driven' and those replicative entrepreneurs are many. Such entrepreneurs are, however, of no relevance to economic growth [22]. Also, Baumol et al. [23] share this opinion but do not completely write replicative entrepreneurship off. Although they concede that it is the innovative entrepreneur who is needed for economic growth, they hardly write replicative entrepreneurship off, arguing that it is relevant in most economies insofar as it serves as a route out of poverty [23].

According to Pahn et al. [24], the authors seem to share the above position that entrepreneurs are not a binding constraint (binding constraints are 'circumstances or factors which, if they remain in place, would hinder growth, even if other possible constraints or determinants of growth are addressed, [22] in poor economies. They rather identify government influence as the significant determinant of economic growth [24]. In another study by $\mathrm{Li}$ et al. [25], the authors look at the influence of entrepreneurship on economic growth with a panel data set from twenty-nine provinces in China over twenty years; their findings display that entrepreneurship positively clarifies economic growth. Despite the view that Africa is the richest continent in the world in terms of minerals and natural resources for which reason entrepreneurship should flourish on the continent, the continent's entrepreneurial performance has been abysmal [26]. This abysmal performance, according to experts, should be blamed on factors such as lack of sensitivity of raw agricultural products to international prices, poor infrastructure, lack of human and financial capital; quality standards, inappropriate trade policies, poor management of human resources, and government policies that are hostile to entrepreneurship [27] study establishes that Africa can boast of many entrepreneurs who have the competence to spot business opportunities and to take advantage of them. However, African private entrepreneurs are deficient in financial and managerial ability to operate large and sophisticated businesses [28]. This raises the question as to whether entrepreneurship in Africa promotes economic growth. Answering this question is the focus of this study.

\section{Other determinants of economic growth}

One determinant of economic growth that has galvanized a lot of empirical attention is financial development. Investigations into the relationship between finance and economic growth have reported conflicting outcomes. Whereas studies such as Jalil and Feridun [29], Tran [30], Waqabaca [31], Levine et al. [32] find a positive relationship between finance and growth, studies such as Adusei [33,34], Hye and Islam [35], Adusei [36], Liang and Reichert [37] and Ram [38] report a negative relationship between the two. Few studies have reported an insignificant relationship between finance and growth $[39,40]$.

Human capital is one of the documented determinants of economic growth. Most studies that have investigated the relationship between human capital accumulation and economic growth have adopted two approaches: accounting framework [41] and endogenous model $[42,40]$. The growth accounting framework submits that education supports economic growth by increasing the human capital stock of individuals and improving their productivity. The endogenous growth model contends that the creation of innovative ideas is a direct function of human capital which finds its expression in the form of scientific knowledge. Thus, investment in human capital drives growth in physical capital and this, in turn, culminates in economic growth. Human capital accumulation might stimulate growth by catalysing technology adoption [43] or human capital might be necessary for technology use [44].

There are four principal predictions in the literature relating to the impact of inflation on output and growth [45]. The first prediction, credited to Sidrauski [46], forecasts that inflation has no effect on growth (money is super-neutral). The second prediction, attributed to Tobin [47], is that money is a substitute for capital, causing inflation to have a positive effect on long-run growth. The third prediction (cashin-advance model) propounded by Stockman [48], sees money as complementary to capital, predicting that inflation should have a negative impact on long-run growth. The fourth prediction is predicated on Huybens and Bruce's [49] new class of models in which inflation is predicted to have a negative impact on long-run growth, but only if its level is above a threshold level. The models posit that financial market efficiency is influenced by various informational asymmetries. For instance, high rates of inflation typically exacerbate financial market frictions, obstruct the efficiency of the financial system and thus undermine economic growth. Indeed, inflation is identified as one of the most important determinants of growth [50].

The literature emphasizes the value of openness to international trade, both as a means of affecting the transfer of technical progress and as an engine of growth $[51,52]$. Trade, either in the form of exports or imports represents growth-enhancing interactions (specialization, exchange of ideas through exports or acquiring foreign technology through quality imports) among countries acting as a channel for knowledge dissemination; thus, more open economies should chalk higher growth rates [53]. Anyanwu and Yameogo [54] report that trade openness has a positive relationship with foreign direct investment (FDI) inflows in Central, North, Southern, and West Africa. This finding is refreshing because it has been observed that FDI can be instrumental to Africa's development efforts [55].

The neoclassical growth theory posits that a rise in investment level increases the steady-state level of output per worker and, therefore, increases the growth rate of output. On the other hand, the endogenous growth theory uses economies of scale and spillover effects to support the way improved investment promotes growth [53]. In short, the two theories predict a significant impact of investment level on economic growth. Government spending is known to influence economic growth. It is on record that government's productive spending on education, infrastructure or some other productive capital positively drives growth. On the other hand, unproductive government spending could undermine growth [56].

\section{Entrepreneurship as an intervention strategy to poverty alleviation}

Widespread poverty had been a prolonged challenge in Sub-Sahara Africa Country. Currently, Africa is the largest continent with the highest number of people living in extreme poverty which accounted for about 383 Million people living with less than $\$ 1.90$ per day, according to World Bank. Generally, in examining poverty in subAfrica, we consider of all sub-sharia African country. According to Global development, nearly half all children in sub-Saharan Africa are 
in extreme poverty. Meanwhile Eradicating extreme poverty by 2030 seems to be a distant target as UNICEF and World Bank figures show almost 383 million people survive on less than $\$ 1.90$ a day [57]. This data shows that Nigeria is rated with the highest number of poverty of 86 million seconded by Democratic Republic Congo which accounts for about 55.1 Million people according to World Bank. Considering the poverty in Sub-sharia Africa as stated according to World Bank, around half of those living in extreme poverty by 2020 will hail from hard-to-reach fragile and conflict-affected states, moreover, SubSaharan Africa accounts for half of the global poor [58]. Across the planet, the number of people living in extreme poverty has dropped by more than half since 1990, China is one of the remarkable success stories in poverty reduction. China cut down the level of the poverty line to 15.9 percent from 84 percent la, 2014) [59]. Having gained her sustainable economic prosperity development, Sub-Saharan African need to adopt China development model as a template for own economic emergency. If we exclude the impressive reduction in the number of Chinese citizens living in abject poverty below the $\$ 2$ a day level, the decline in poverty in Asia has been less impressive. This call for a better impact for sub-Sahara Africa nations.

The significant impact of China moving more than billion people lived on under $\$ 1.25$ a day, compared to 836 million in 2015, according to the UN. In 2016, rains failed across large swaths of countries in Eastern and Southern Africa Although weather shocks are not uncommon in Africa, the 2016 drought stands out in scale and severity, because of the unusually large number of countries announcing significant drops in the levels of crop production, especially of staples, at the same time For example, maize production in 2015/16 in the 15 member countries of the Southern African Development Community (SADC) fell by an average of 19 percent compared with the 2014/15 maize season Similarly, in Eastern Africa, severe crop and livestock production losses were reported, especially in the Horn of Africa The drought also led to power disruption, depressed economic activity, and increased poverty Drought-induced declines in maize were estimated to reduce gross domestic product in the SADC area by 0.1 percentage point and increase poverty by 1.4 million people. An estimated 260,000 people died from the 2010/2011 famine in the Horn of Africa in 2016, an estimated 250,000 South Sudanese children under the age of 5 were estimated to suffer from severe acute malnutrition.

\section{Entrepreneurship as a catalyst for economic prosperity not aid}

Aid is ineffective. By some estimates, more than $\$ 2$-trillion has been spent fighting poverty since seven decades, with little direct impact. The stories of failure are illustrated with hydro dams that never function, crops that never grew and roads that went nowhere. Entrepreneurs, however, are changing the world. Since 2005, an estimated half-billion people or more have been raised out of poverty, mainly by small business, trade liberalization and gains in productivity. In China, Pakistan, Indonesia, and Nigeria, booming local economies, oblivious to the latest schemes of aid programs, are creating millions of jobs. The Brookings Institution recently predicted even more dramatic gains ahead: "Between 2005 and 2015, India, Bangladesh, Vietnam, and Ethiopia are each expected to grow by at least 6.3 per cent per year, and in the process, each is likely to see a quarter of its population lifted out of poverty." Entrepreneurs, not aid spending, are driving this growth. The creativity that led to this dramatic progress in the fight against world poverty was the grudging realization by donors that aid planners do not create jobs- small business does.

Entrepreneurship is crucial to economic development because of her demography dividend at the same time it large population which creates a huge market. the advantages to Sub-Saharan Africa will be greater if all the governments can encourage it as a survival model in reducing poverty. Entrepreneur paves the way to industrialization; industrialization strategies could better target high-potential entrepreneurial activities to accelerate industrialization. Entrepreneurs play an essential role in bringing innovation to an economy, notably innovative technologies and production methods. According to African Economic Outlook 2017, Entrepreneurship also pushes up total productivity through the process of "churning". New innovative firms put pressure on older firms to innovate. Entrepreneurship encourages diversification into new economic sectors and adapts foreign technologies to local markets for its growth. It's bolstering industrialization by efficiently shifting resources away from traditional sectors into more modern one. Landes express that entrepreneur serves as a solution provider where government failed to function, it is often seen as a mechanize that provides public service left by the governments. High-potential entrepreneurs also experiment with new products in local markets. They offer fresh ideas and exchange information with other local producers, potentially increasing competitiveness by shifting resources to higher-productivity activities.

However, scientific facts on the relationship between economic growth and entrepreneurship is conflicting Van Stel et al. [9] stated that entrepreneurship has a significant relationship with per capita GDP in developed nations, Reynolds et al. [10] reports negative relationship performance and real per capita GDP among all the nations studied. Entrepreneurship contributes to economic growth and diversification. It drives structural transformation and industrialization leading to inclusive and sustainable socio-economic development. As entrepreneurs start and grow their firms, they transform the economy and drive broader outcomes contributing to the global sustainable development agenda and SDG's Goal 8 describes the need for promoting sustainable economic growth. These will result in the promotion of full and productive employment and descent work for all. Sub-Saharan governments should embrace this goal as it advocates for policies promoting job creation and full and productive employment and entrepreneurship can be used as a solution.

\section{Entrepreneurship introduce innovations that induce economic growth}

Over the last four decades, the level of government interest in entrepreneurship and small business development as potential solutions to flagging economic growth and rising unemployment has increased. It helped to spawn a new field of academic study and research. Innovation is the key to modern theories of development and growth [60]. It is evident that with factors such as technological product, costs, and process, innovations have graduated to become one of the keys to competitiveness and business success [60]. Competition in the global economy has now become knowledge-based and this is what countries in Sub-Saharan Africa need to adapt to grow their economic sectors. Most countries in the Sub-Saharan are known of traditional economic sectors such as textiles, leather, and food processing [60], such sectors need innovation and technological advancement for them to support modern entrepreneurship that will bolster economic growth. Governments need to support entrepreneurship and innovation as a way of removing people from 
poverty because innovative entrepreneurship act about changes in the structure of the economy, technological upgrading in production, and moving higher value performing global value chains [60] and this is what impoverished Sub-Saharan African countries needs for development. If the governments can adapt to technological change that embraces the new modern use of machinery and equipment and modern generation of tech-literate educated workers, the region can experience a shift in their economies and will not need handouts from developed countries.

\section{Entrepreneurship provides new job opportunities in the short and long term}

Africa Economic Outlook 2017 shows that about 22 percent of Africa's working-age population is starting a new business, of which Africa is the most rated in the world and companies less than twenty employees less than 5 fives of operations provides most of the job in Africa continent formal sector. Meanwhile, about 44 percent of African entrepreneurs start businesses to utilize the chances in the market, although about 33 percent adopt this as a means of surviving because of the level of unemployment in Africa. Entrepreneurship is the beginning of a fresh start of citizen's financial empowerment that will help provide most of poverty stricken families with employment.

Unemployment is one of the highly proven challenges that are viewed to have a lot of effect on the Sub-Saharan African countries with a high number of the affected populations being the under 25 youth who are unemployed. Entrepreneurship stimulates employment growth by generating new jobs when entrepreneurs enter the market [61]. Research has shown that many Sub-Saharan economies are experiencing slow growth. They are exacerbated by the fiscal crisis; unemployment persists in developing labour markets. And despite sweeping government stimulus packages directed at large institutions entrepreneurship has emerged as one of a few sources of economic activity that can successfully contradict these trends [62]. Taking the United States as an example of how efficient entrepreneurship can create employment and reduce poverty.

For Africa countries to be committed to promoting sustainable job creation, they must foster entrepreneurship. Sub-Saharan African countries remain most demographical populous continent, which accounts for more than half of her population under age of 25 years and youth unemployment is the largest in absolute terms when comparing other parts of the world. Job creation for the younger generation is still lingered to be a bottle neck and it is the most critical issue for the future. According to the World Bank 2015 [63], 600 million Jobs are required in the next one and half decades in other for catching up with the growing global workforce majorly among mainly in Asia and Sub-Saharan Africa, however, most of these formal jobs in developing economies are created within the arms of entrepreneur which also employees 4 out of 5 new positions [64]. This shows that there is a significant relationship between Entrepreneur growth and economic prosperity. Entrepreneurship can tap into the growing pool of Africa's youth, who are increasingly skilled and competitive. Meanwhile regional country has not significantly reduced poverty among youth without experiencing unemployment.

In reducing poverty in sub-Sahara, development economic and economic history have previously given series of meaning to poverty and its solution such as $[65,66]$ Strengthen economic prosperity and poverty reduction. Scientific scholars have often geared attention on scale and scope economies and maximizing output [67]. Although scholars in the field of management and economists constantly observed that entrepreneurship may generate a substantial part of SubSaharan Africa solution to poverty due to her unemployment rates. Entrepreneurship helps in poverty reduction when it is creating employment through the establishment of new entrepreneurship or the developing of existing ones which increase economic wealth by creating new markets, new industries, innovative technology, new institutional forms, new jobs and net increases in real productivity, increases income which pick higher standards of living for the population. This simply implies that the more the number of entrepreneurs in each country the poverty line will automatically be at a minimal rate [68]. In order for Sub-sharia Africa countries to get out of poverty, there is the need for entrepreneurial development through new jobs creation and provide income for the people [69]. The strategic significance of entrepreneurial in national economic development is widely recognized $[68,70]$.

The Entrepreneurial intent was highest in sub-Saharan Africa, where more than one in three respondents (35\%) planned to start business [71]. Considering Gambian, where Entrepreneurship business employee 60 percent of its population ranging from 15 to 64 years age and also contributed about 20 percent of GDP [72]. The report also shows and confirms that 70 percent of her citizens are self-employed. A recent study in Ghana and South Africa also showed the same result. Small and medium sized enterprises contributed to 52 percent to 57 percent of GDP and around 61 percent of employment in South Africa, and 85 percent of manufacturing employment and 70 percent of GDP in Ghana. Currently, in Nigeria, more than 1600 university and colleges are offering entrepreneurship and small business management program when comparing to the number in the college offering the course in the 1990s. Also, 86 percent of the youth are looking forward to becoming entrepreneurs and this shows the positive view by following Nigerians. According to (Governments, n.d.) 63 percent of its survey respondents expressed Nigerians admiration for entrepreneurs.

Generally, in Africa Continent, 80 percent believe that the entrepreneurial culture is animated and Entrepreneurship has been viewed as a good career opportunity [73]. Presently in the entire world, the continent has the highest share in the world of adults starting or running new businesses. According to Forbes Figure 1 shows that in Sub-Saharan Africa entrepreneurs are looked to as a source for job incubators with about 59 percent respondents agreed to that with a large expectation they have from their countries' entrepreneurs. The contribution of the entrepreneurs' potentials ability to proactively accord to Sub-Saharan Africa economic prosperity cannot be overstated, considering that the nation themselves only gained independence from colonial rule in the past view decades and to varying degrees experienced the post-independence conflict that left the region politically and economically unstable for years.

The effect of entrepreneur gives extra weight when considering the strength of the market it can operate; Sub-Saharan is dominated by large powerful natural resource sectors and deep-pocketed multinational companies but is forced to contend with series of infrastructure issues. According to the principal, Country Economist at the Africa Development Bank explores furthermore about Mozambique, their economic growth with foreign investment into capital investment but with a lower employment project. Nigerians, on the other hand, appreciate entrepreneurs more as the drivers of the new economy and as indicators of the positive shift away from dependence on the oil sector. 


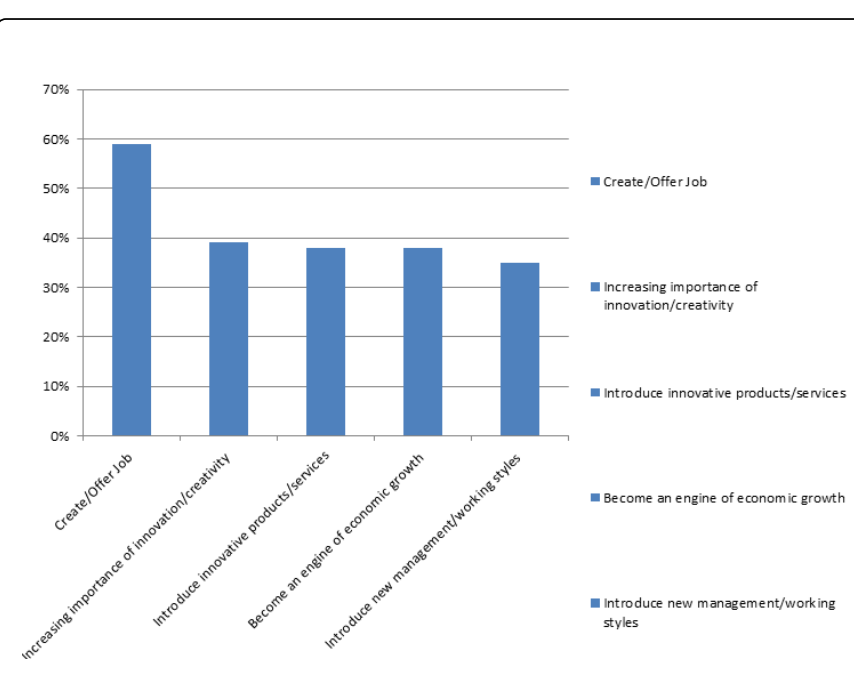

Figure 1: How entrepreneurs can help develop the economy.

\section{Discussion}

\section{Challenges faced by entrepreneurs in Sub-Saharan Africa}

Challenges of internal capacity building constraint: Every start-up firms globally faced that challenges of finding experienced managerial talent to complement a technical team. Just because someone is a remarkable engineer or developer does not mean they can make a good CEO or manager [74]. With little incentive or financing for prospective employees, beginners frequently lose out on the best talent, who get snatched up by larger, well-established companies like as banks and telecoms. According to report, the limited pool of skilled managerial talent is in most situation connected to the education system. "Numerous African education system centre on preparing the workforce for employment by more-established companies. The existence (or dearth thereof) of entrepreneurship training in the education system plays a significant role in this debate. In Africa, entrepreneurs require education and training to permit them to succeed in opening or growing a business. Additionally, entrepreneurs need a skilled workforce to meet their business targets." By building a relationship such as the strategy to action in the minds of the very young, the very foundations on which the firms base their theoretical knowledge and technical skills which are required at the adult age to constantly be in action, innovate and manage with the best guarantees of efficiency. Ncube (2013) asserts that the dearth of high and technological related skills lessens the prospects for moving up the value chain in industries, which end up lessening labour productivity and existing industries' competitiveness. Additionally, in Africa, the slow headway of adapting to the novel and emerging technologies influence productivity and growth. This scenario has contributed to local economies void of a competitive advantage as well as making these firms lagging those of other industrialized nations.

Environmental challenges for entrepreneurship: The literature considers the effect of environmental conditions on entrepreneurs [75]. In their study of environments for entrepreneurship, Gnyawali and Fogel [75] used "entrepreneurial environment" to capture the combination of factors critical to entrepreneurship. First is the general environment encompassing "the overall economic, sociocultural, and political factors that influence people's willingness and ability to undertake entrepreneurial activities?" Second is the "availability of assistance and support services that facilitate the start-up process. In a study that contrasted motivations and environment with the rate of firm start-ups, Dubini [76] identified three types of environments that have ramifications for the rate of new venture creation: munificent environments, characterized by efficient infrastructure, established capital markets and the availability of incentives to start business; supportive environments, in which the creation of an infrastructure specifically aimed at encouraging new firms could lead to a significant boost in entrepreneurship; and sparse environments, in which both infrastructure and capital availability are lacking. Many African entrepreneurs operate in the sparse environment. This section considers the following specific challenges: business climate, access to credit, and physical infrastructure.

Challenges of business climate to entrepreneurship: Gatewood and Boko [77] state that in "many developing countries, budding entrepreneurs are discouraged by the mound of regulations and the costs in time and money necessary to start and register a business." The rankings of the Doing Business Index by the World Bank [78] show that the highest cost of starting a business in the Democratic Republic of Congo (DRC) is 487 percent, compared to a mere 0.7 percent in the U.S. It takes almost a year to complete the licensing processes in Benin and DRC, compared to 40 days in the U.S. The costs of obtaining licenses are almost 3000 percent in Niger; 2000 percent in the DRC; and about 1000 percent in Mali, but just 13.4 percent in the USA $[77,78]$.

For ease of doing business, 2011 Doing Business Index puts Nigeria at an aggregate of 137; Sierra Leone, 143; Gambia, 146; Burkina Faso, 151; Senegal, 152; and Benin, 170 out of 183 countries [79]. A 2015 World Bank study ranked 189 countries on ease of doing business (Table 1).

\begin{tabular}{|l|l|l|l|l|l|l|l|l|l|l|}
\hline Variables & $\begin{array}{l}\text { South } \\
\text { Africa }\end{array}$ & $\begin{array}{l}\text { Rep. of } \\
\text { Korea }\end{array}$ & Ghana & Brazil & Kenya & Mexico & Nigeria & Peru & Eritrea & Singapore \\
\hline $\begin{array}{l}\text { Ease of doing } \\
\text { business rank }\end{array}$ & 43 & 5 & 70 & 120 & 136 & 39 & 170 & 35 & 189 & 1 \\
\hline Starting a bus & 61 & 17 & 96 & 167 & 143 & 67 & 129 & 89 & 183 & 6 \\
\hline $\begin{array}{l}\text { Registering } \\
\text { property }\end{array}$ & 97 & 79 & 36 & 138 & 136 & 110 & 185 & 26 & 176 & 24 \\
\hline Getting credit & 52 & 36 & 36 & 89 & 116 & 12 & 52 & 12 & 185 & 17 \\
\hline
\end{tabular}




\begin{tabular}{|l|l|l|l|l|l|l|l|l|l|l|}
\hline $\begin{array}{l}\text { Dealing with const. } \\
\text { permit }\end{array}$ & 32 & 12 & 106 & 174 & 95 & 108 & 171 & 87 & 189 & 2 \\
\hline Getting electricity & 158 & 1 & 71 & 19 & 151 & 116 & 189 & 86 & 113 & 11 \\
\hline $\begin{array}{l}\text { Protecting } \\
\text { investors }\end{array}$ & 17 & 21 & 43 & 35 & 122 & 62 & 62 & 40 & 166 & 3 \\
\hline Paying taxes & 19 & 25 & 56 & 177 & 102 & 105 & 179 & 57 & 174 & 1 \\
\hline $\begin{array}{l}\text { Trading across } \\
\text { borders }\end{array}$ & 101 & 3 & 101 & 128 & 153 & 44 & 159 & 55 & 172 & 1 \\
\hline
\end{tabular}

Table 1: Ease of Doing Business, 2015.

Countries are ranked from 1-189 (1 the highest, 189 the lowest). A high ease of doing business ranking means the regulatory environment is conducive to starting and operating a local firm. The table shows comparative rankings of five African and five other countries. First, the table shows an aggregate score for each country as well as rankings for eight sub-categories. Singapore ranks the highest (1) out of 189 countries on ease of doing business.

As the table also shows, except South Africa (43) and Ghana (70), the other three African countries rank in three digits. In fact, much of African countries are at the bottom of the list. No African country compares to the Republic of South Korea (5), Mexico (39), and Peru (35) on the aggregate ease of doing business index. This suggests that business environments in many African countries are not conducive to entrepreneurship and MSME development.

Challenges of access to funding: Finding access to funding when it comes to starting a business is problematic; the challenge is one of the biggest concerns influencing potential entrepreneurs globally [80]. The significance of private sector development and its vital role in funding and accelerating Africa's economic transformation cannot be overstated. In some developing markets, institutional funding for entrepreneurs remains limited in countries studied. Over 45 percent of entrepreneurs mentioned that funding came from either their own savings or family loans, while over 71 percent of entrepreneur mentioned that the cost of accessing equity capital, debt or loans is prohibitively expensive [74]. So, the International Finance Corporation, up to 84 percent of entrepreneurs in Africa are either underserved or unserved, highlighting a massive credit funding gap of $\$ 140$ to $\$ 170$ United States dollars. Financiers, nevertheless, claim that most ventures simply are not fundable or do not seem viable. Venture capitals especially cite a dearth of a good business plan, quality and feasibility of the business idea, and perceived commitment of the entrepreneur as reasons for the slow deal flow. Given the significant role that entrepreneurship is believed to play in the process of creative destruction and hence economic expansion, it is not surprising that attempts to reduce funding constraints for would-be entrepreneurs is a significant goal for policymakers globally [80]. Therefore, monetary assistance is also high on the agenda in the European Union and OECD, where member states are urged to foster the availability of risk capital funding for entrepreneurs.

Challenges of access to credit and entrepreneurship: Sustained entrepreneurship requires supportive and accessible financial institutions, such as commercial banks, development finance institutions, microfinance banks, credit bureaus, and money deposit banks. In most African countries, financial institutions are underdeveloped, and access to credit is limited. Data from the World
Bank Enterprise Surveys indicate that one of the key impediments to firms in Africa is a lack of access to credit [81]. Financial institutions demand outrageous collaterals as a condition sine qua non for extending investment loans. Figure 2 shows that compared to developing countries in other regions, African countries rank poorly with regards to accessibility of entrepreneurs to credit.

In Ghana, collateral is 240 percent of the value of the loan amount. However, collateral requirements vary from micro enterprises to large firms: 260 percent for the micro enterprise; 213 percent for small enterprises; 213 percent for medium enterprises; and 216 percent for large enterprises. Nigeria had an aggregate of 228 percent, while collateral required for micro enterprises, small, medium, and large firms are 223 percent, 228 percent, 286 percent, and 207.4 percent, respectively [81]. Developed and efficient financial systems minimize the dependence of entrepreneurs on internal funds or personal and informal sources, such as family and friends. Excessive dependence on internal funds for investment is an indication of potentially inefficient financial intermediation [81].

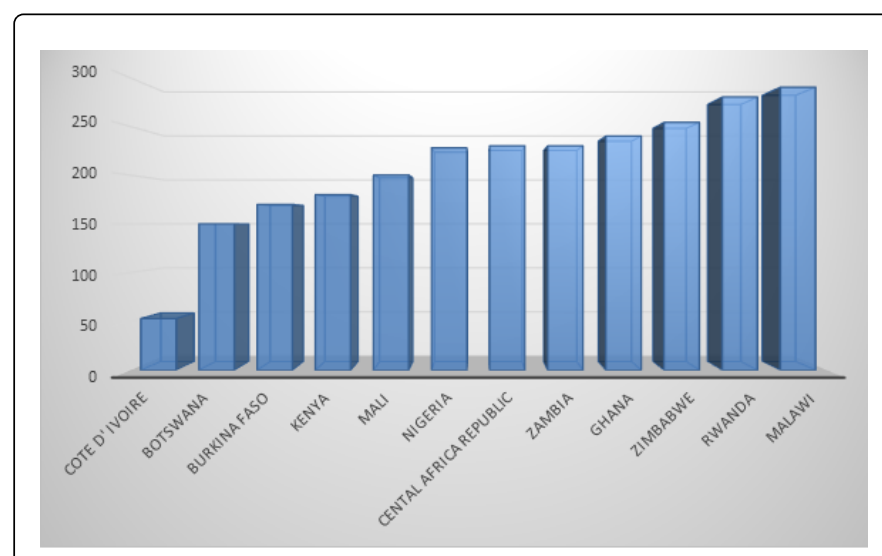

Figure 2: Access to credit.

Due to underdeveloped and inefficient financial markets to serve the needs of MSMEs, entrepreneurs commonly resort to internal or personal funds for investment. In Nigeria, 53 percent of firms depend on internal funds for investment, while it is 76 percent in Ghana, 61 percent in Kenya, 85 percent in Tanzania, and 72 percent in Senegal [81]. Weak financial institutions hamper business operations and expansion, stifle the ability of entrepreneurs to take advantage of potential market opportunities, and discourage start-ups. 
Challenges of physical infrastructure and entrepreneurship: In some countries like Kenya, a high-speed fibre optics backbone has enabled an ecosystem of ICT entrepreneurs to build apps and the web and mobile services, in other connections are dismal and a dearth of physical infrastructure presents a huge barrier [74]. The poor condition of infrastructure across sub-Saharan Africa is a crucial challenge to the expansion of entrepreneurial enterprises; it seriously creates a huge problem for entrepreneurs' in terms of efficiencies, costs, and market access. Looking at the significant impact on the cost of doing business, infrastructure is highlighted as having a significant influence on the success and growth of the entrepreneurs. This is because over 52 percent of respondents in Tanzania believe that new and growing companies cannot afford the costs of physical infrastructure. Across the continent of Africa, only 38 percent of entrepreneurs agree that infrastructure offers adequate backing for novel and growing companies, and only 23 percent believe that novel and growing companies could afford the costs of using infrastructure.

A strong national physical infrastructure is critical to the competitiveness of economy [63]. Agboli and Ukaegbu [82] emphasized the critical nature of physical infrastructure for Nigerian entrepreneurs. Physical infrastructure includes transportation (roads and highways, seaports, airports, and railroads), telecommunications, and electric power generation. The presence of infrastructure helps to create an environment not only conducive to locating a business, but also supportive of start-ups, growth, and expansion. Physical and efficient infrastructure, such as transportation, helps to link MSMEs to their customers, suppliers, and markets. In virtually all African countries, deficient infrastructure remains the bane of new venture start-ups, growth, and expansion.

Transportation/Logistics: Most African nations face weak communications, inferior quality and limited breadth of rail network and road. The critical nature of logistics for MSMEs lies in creating value for customers and suppliers. As Hamisi [83] pointed out, the value in logistics is expressed in time and place: "Product and services have no value unless they are in the possession of the customers when (time) and where (place) they wish to consume them." According to UNCTAD [84], firms, particularly MSMEs, in developing countries are unable to benefit from the opportunities offered by global value chains because of their low connectivity to global transportation networks and their weak productive capacity.

Entrepreneurs and MSME operators in Africa face physical infrastructure challenges. Compared to other developing countries, African countries fared poorly on the 2012-2013 Global Competitiveness rankings of 142 countries on the infrastructure. On the quality of overall infrastructure, the leading high performers were Namibia, 40; South Africa, 58; Botswana, 64; and Zambia, 84. These stood in sharp contrast to Ethiopia, 100; Uganda, 110; Malawi, 116; Nigeria, 117; and Angola, 138 [85]. The World Bank Logistics Performance Index (LPI) shows that African countries ranked poorly out of 160 countries [81]. Compared to other developing countries with higher scores, such as South Korea (21), Malaysia (25), and Taiwan (19), only eight African countries rank among the first 100 countries, ranging from South Africa (34) to Ghana (100). This demonstrates "higher logistics costs borne by SMEs as a source of missing the opportunities of globalization" [83]. Due to deficient transportation systems in many African countries, "moving of goods from one point to another exacts excessive costs" [86].

Electricity power generation: For most entrepreneurs, the greatest obstacle when it comes to running a successful business is the dearth of electricity; most African nations faced unreliable power supply. In subSaharan Africa, the cost to get electricity as a percentage of income per capita is 4,747 percent, compared to 1,895 percent in South Asia [85]. Unreliable power situation adds to start-up and production costs. A 2005 survey by Manufacturing Association of Nigeria found that the costs of generating power accounted for about 36 percent of the production costs [87]. Based on the World Bank Surveys, the Global Entrepreneurship report indicates that, among 142 countries captured, the rankings for the quality of electricity for certain African countries are: Ethiopia, 112; Ghana, 116; Malawi, 128; Uganda, 129; Angola, 135; and Nigeria, 138 [85].

Inferior quality power supply affects labour productivity and output. A study found that inferior quality electricity supply is the infrastructure element that has the strongest negative impact on firm productivity, especially in poor African countries [88]. Arnold et al. (84) used World Bank Enterprise Surveys data for over 1,000 firms in 10 sub-Saharan African countries to show that an unreliable electricity supply has a significant negative effect on a firm's total factor productivity. Moyo [87] examined the impact of power disruptions on firm productivity in Nigeria's manufacturing sector and found that power outage variables (measured by hours per days without power and percentage of output lost due to power disruption) have a negative and significant impact on productivity. Power outages and disruptions have created an undesirable phenomenon in Africa as entrepreneurs' resort to backup generators to meet their business needs. As Africa increasingly becomes a dumping ground for individual power generating plants, the severity of noise and air pollutions has intensified.

Overcoming the challenges of infrastructure in Africa would significantly enhance the level of entrepreneurship and improve productivity. Enhanced infrastructure will foster the prospects of MSME viability and success. For example, the Manufacturing Association of Nigeria attributed the closure of 820 manufacturing companies in the country between 2000 and 2008 and of a further 834 in 2009 alone to the inflated costs of infrastructure $[89,90]$. Besides being critical to entrepreneurs, improved infrastructure will help make economies of African countries more competitive and attractive for foreign investment.

When it comes to entrepreneurs in Africa, it could appear hopeless, or at least rather depressing. This is because the financing, infrastructure, and talent challenges are not easy to solve, they demand large scale, systematic overhauls to create an enabling environment for Africa's entrepreneurs [73]. Irrespective of all these challenges faced by entrepreneurs in Africa, one would disagree that entrepreneurs are still succeeding. Out of the ten fastest growing economy in the world, six of the countries are in Africa; if active stakeholders (NGOs, Universities, and government) could find a solution to what is not working, one can only imagine the potential. Inadequate and undependable physical infrastructure features prominently as an obstacle to the fruitful establishment and expansion of business ventures. Poor power supply, poor communications, mediocre quality and limited breadth of rail networks and road infrastructure are highlighted as having a vital influence on the cost of doing business in African nations. The poor infrastructure situation is the most notable constraint highlighted by respondents, with electricity supply emerging as the most important obstacles faced by African entrepreneurs. 


\section{Conclusion}

This research revealed that entrepreneurs play a huge and significant role in Sub-Saharan Africa by creating jobs and stimulating both competition and innovation. It also informed us that the sub-Saharan Africa entrepreneur is the key player toward poverty elevation and employment. As a key driver of employment growth, the government and all other stakeholders must do everything they can to aid entrepreneurs and enhance economic prosperity. Hence, most importantly, entrepreneurship creates regional blocks, inter-firm linkage. This creates development towards economic leading to poverty reduction; stimulating employment as well as fast-tracking poverty reduction within the regions. Finally, we found that innovation, entrepreneurship curriculum training and education, individual entrepreneurial characteristics, the participation of micro, small and medium enterprises, youth empowerment, the collaboration of government-university-industry are the key tool for entrepreneurship development which is stimulating employment are eventually alleviating poverty. Maximizing and capitalizing on SMEs is essential for Sub-Saharan Africa because of all the factors relating to economic growth that if ignored might be fatal for its rising economy. With a very young population and not enough jobs to offer, SMEs are the only solution for the regions.

\section{Policy Recommendations}

- African governments need to include vocational training and entrepreneurial in the education system of their respective nations so that their people are exposed to entrepreneurship from childhood. In addition, network programs and mentorship should be instituted in their various high institution where experienced executives (presently or previous employed) can give backing to businesses for limited periods by working alongside and training staff on major projects.

- African governments need to provide incentives such as subsidies and tax holiday to entrepreneurs who provide strong employee value propositions to prospective professional staff, like specialized training or stock option programs.

- African governments should offer targeted incentives to entrepreneurs for the development of major sectors that are presently underserved and business development services to set up business support services firms.

- African governments should introduce a policy that will help improve the physical infrastructure-power, broadband internet, transportation, particularly in the more rural regions. African government should lessen bureaucracy linked with opening a business and fight corruption.

\section{References}

1. Dau 1A, Cuervo-cazurra A (2014) To formalize or not to formalize: Entrepreneurship and pro-market institutions. J Bus Vent 29: 668-686.

2. Sarkar S (2014) International journal of finance and policy analysis. London: Universal Publishers, UK.

3. Adebayo A (2013) Youth unemployment and crime in Nigeria: A nexus and implications for national development. Int J Sociol Anthropol 5: 350-357.

4. International labor organization (ilo) (2012) Youth employment interventions in Africa: A mapping report of the employment and labor sub-cluster of the regional coordination mechanism $(\mathrm{rcm})$ for Africa/ International labor organization-regional office for Africa. Addis Ababa: Ilo, 2012.
5. Forsman H (2011) Innovation capacity and innovation development in small enterprises. A comparison between the manufacturing and service sectors. J Respol 40: 739-750.

6. Mckeever E, Anderson A, Jack S (2014) Entrepreneurship and mutuality: Social capital in processes and practices. Ent Reg Devl 26: 453-477.

7. GEM (Global Entrepreneurship Monitor) (2014) Informe gem españa 2013 (gem spain report 2013). Red española de equipos regionales spanish network of regional teams, Spain.

8. Audretsch DB, Keilbach MC, Lehmann EE (2006) Entrepreneurship and economic growth, Oxford University Press, New York, USA.

9. Van Stel A, Carree M, Thurik R (2005) The effect of entrepreneurship on national economic growth. Small Bus Econ 23: 311-321.

10. Reynolds P, Bygrave WD, Autio E (2003) Global entrepreneurship monitor 2003 executive report: Babson college. London Business School, Ewing Marion Kauffman Foundation, UK.

11. Iyigun ME, Owen AL (1998) Risk, entrepreneurship, and human capital accumulation. Am Econ Rev 88: 454-457.

12. Yamada G (1996) Urban informal employment and self-employment in developing nations: Theory and evidence. Econ Dev Cult Change 44: 289-314.

13. Schultz TP (1990) Women's changing participation in the work force: A global perspective. Econ Dev Cult Change 38: 457-488.

14. Baumol WJ (2014) Stimulating growth amid recession: entrepreneurship, innovation, and the keynesian revolution. J Jpolmod 36: 629-635.

15. Jiang N, Wang P, Wu H (2010) Ability-heterogeneity, entrepreneurship and economic growth. J Jedc 34: 522-541.

16. Audretsch DB, Bonte W, Keilbach M (2008) Entrepreneurship capital and its impact on knowledge diffusion and economic performance. J Bus Vent 23: 687-698.

17. Mueller P (2006) Exploring the knowledge filter: How entrepreneurship and university-industry relationships drive economic growth. Research Policy 35: 1499-1508.

18. Mueller P (2007) Entrepreneurial opportunities: the impact of entrepreneurship on growth. Small Bus Econ 28: 355-362.

19. Stefanescu D (2012) Entrepreneurship in international perspective. Proc Econ Fin 3: 193-198.

20. Harbi SE, Grolleau G, Bekir I (2011) Entrepreneurship and growth: What causes what? Advances in the study of entrepreneurship. Inno Econ Grow 22: 73-91.

21. Galindoa M, Mendez MT (2014) Entrepreneurship, economic growth, and innovation: are feedback effects at work? J Jbusres 67: 825-289.

22. Naude W (2011) Entrepreneurship is not a binding constraint on growth and development in the poorest countries. World Dev 39: 33-44.

23. Baumol WJ, Litan RE, Schramm CJ (2007) Good capitalism, bad capitalism and the economics of growth and prosperity, Yale University press, New Haven, USA.

24. Pahn PP, Venkataraman S, Velamuri SR (2008) Entrepreneurship in emerging regions around the world: theory, evidence and implications, edward elgar, Cheltenham, England.

25. Li H, Yang Z, Yao X, Zhang H (2012) Entrepreneurship, private economy and growth: evidence from China. China Econ Rev 23: 948-961.

26. Kshetri N (2011) Institutional and economic foundations of entrepreneurship in Africa: An overview. J Dev Entrep 16: 9-35.

27. Robson PJA, Obeng BA (2008) The barriers to growth in Ghana. Small Bus Econ 30: 385-403.

28. Wilson EJ (1990) Strategies of state control of the economy: nationalization and indigenization in black Africa. Comp Politics 22: 401-419.

29. Jalil A, Feridun M (2011) Impact of financial development on economic growth: empirical evidence from Pakistan. J Asia Pacific Econ 16: 71-80.

30. Tran AT (2008) Financial development and economic growth in the case of vietnam. J Int Bus Econ 8: 135-153.

31. Waqabaca C (2004) Financial development and economic growth in fiji. Economics Department, Reserve Bank of Fiji, working papers, Fiji. 
32. Levine R, Loayza N, Beck T (2000) Financial intermediation and growth: causality and causes. J Monetary Econ 46: 31-77.

33. Adusei M (2013) Financial development and economic growth: evidence from Ghana. Inter J Bus Fin Res 7: 61-76.

34. Adusei M (2013b) Does finance promote growth in botswana? Res Appl Econ 5: 70-81.

35. Qma H, Islam F (2013) Does financial development hamper economic growth: Empirical evidence from Bangladesh. J Bus Econ Man 14: 558-582.

36. Adusei M (2012) Financial development and economic growth: is schumpeter, right? British J Econ Manag Trad 2: 265-278.

37. Liang H, Reichert AK (2012) The impact of banks and non-bank financial institutions on economic growth. Serv Industries J 32: 699-717.

38. Ram R (1999) Financial development and economic growth: Additional evidence. J Develop Stud 35: 164-174.

39. Guryay E, Safakli OV, Tuzel B (2007) Financial development and economic growth: evidence from northern cyprus. Int Res J Fin Econ no. 8.

40. Lucas RE (1988) On the mechanics of economic development. J Monet Econ 22: 3-42.

41. Samimi A, Adadi M, Heydarizade N (2012) An estimation of human capital share in economic growth of Iran using growth accounting approach. Middle-East J Sci Res 1: 90-93.

42. Grossman G, Helpman E (1991) Innovation and growth in the global economy, Mit Press, Cambridge, MA.

43. Foster A, Rosenzweig M (1996) Technical change and human capital returns and investments: Evidence from the green revolution. Am Eco Rev 86: 931-593.

44. Easterly W, King R, Levine R, Ebelo S(1994) Policy, technology adoption and growth. In: Pasinetti, Solow (eds.), Economic growth and the structure of long term development, St Martin's Press, New York, USA.

45. Drukker DP, Porqueras G, Hernandez-Verme P (2005) Threshold effects in the relationship between inflation and growth: A new panel-data approach. Proceedings of the 11th International Conference.

46. Sidrauski M (1967) Inflation and economic growth. J Polit Econ 796-810.

47. Tobin J (1965) Money and economic growth. Econometrica 33: 671-184.

48. Stockman A (1981) Anticipated inflation and the capital stock in a cashin-advance economy. J Monet Econ 8: 387-393.

49. Huybens E, Bruce DS (1998) Financial market frictions, monetary policy and capital accumulation in a small open economy. J Econ Theory. 81 353-400.

50. Ghosh A, Phillips S (1998) Warning: Inflation may be harmful to your growth. Imf Staff Papers 45: 672-710.

51. Saci, Giorgioni G, hHolden (2009) Does financial development affect growth? Applied Economics 41: 1701-1707.

52. Zang H, Kim YC (2007) Does financial development precede growth? Robinson and lucas might be right. Applied Econ Lett 14: 15-19.

53. Apergis N, Filippidis I, Economidou C (2007) Financial deepening and economic growth linkages: A panel data analysis. Weltwirtsch Arch 143: 179-198.

54. Anyanwu JC, Yameogo ND (2015) Regional comparison of foreign direct investment to Africa: Empirical analysis. Afr Dev Rev 27: 345-363.

55. Anyanwu JC (2006) Promoting of investment in Africa. Afr Dev Rev 18: $42-71$.

56. Barro RJ, Sala-i-Martin (1995) Economic growth, Mcgraw Hill, Boston, MA, USA.

57. https://www.theguardian.com/global-development/2016/oct/05/nearlyhalf-all-children-sub-saharan-africa-extreme-poverty-unicef-worldbank-report-warns.

58. https://www.theguardian.com/society/2015/oct/05/world-bank-extremepoverty-to-fall-below-10-of-world-population-for-first-time.

59. Ayodele T, Sotola O (2014) China in Africa: An evaluation of Chinese investment.
60. Szirmai A, Naudé W, Goedhuys M (2011) Entrepreneurship, innovation, and economic development: An overview.

61. Alexander S (2014) Entrepreneurs and their impact on jobs and economic growth. Iza World of Labor 3-10.

62. http://www.imd.org/news/Creating-entrepreneurs-that-createopportunities-the-Effectual-Entrepreneurship-textbook.cfm.

63. World Bank (2015) Doing business 2015: Going beyond efficiency. Washington, DC: World Bank, USA.

64. http://www.worldbank.org/en/topic/financialsector/brief/smes-finance.

65. Ashworth W (2011) Review: Mccloskey (2010) bourgeois dignity: Why economics can't explain the modern. Bus History 53: 656-659.

66. Perkins DH, Radelet S, Lindauer DL, Block SA (2012) Economics of Development. (7th edn), Norton, W. W. \& Company, Inc. USA.

67. Naim M (2013) The end of power: from boardrooms to battlefields and churches to states, why being in charge isn't what it used to be. (1st edn). New York: Basic Books, USA.

68. Cob B, Utara U (2014) Entrepreneurship development and poverty alleviation: An empirical review. Mohammad Delwar Hussain Abu MD, 1 Rosni Bakar BB (eds) 4: 558-573.

69. http://www.un.org/africarenewal/magazine/april-2016/africa-looks-itsentrepreneurs.

70. Kareem RO (2015) Impact of entrepreneurship on poverty alleviation. J Bus Admin Edu 7: 1-16.

71. http://www.gallupcom/poll/177644/entrepreneurial-plans-highest-subsaharan-africa.asp.

72. Fund AD (2006) Language: English republic of the gambia entrepreneurship promotion and microfinance development project appraisal report, (August).

73. African Pulse (2017) An analysis of issues shaping Africa's economic future. World Bank Group, USA.

74. Kalan J (2013) How to accelerate entrepreneurship in Africa. Accessed through Google on 14 October.

75. Gnyawali Devi R, Fogel Daniel S (1994) Environment for entrepreneurship development: Key dimensions and research implications. Entrepreneursh. Theory Pract 18: 43-62.

76. Dubini P (1989) The influence of motivations and environment on business start-ups: Some hints for public policies. J Bus Vent 4: 11-26.

77. Gatewood Elizabeth J, Sylvain B (2009) Globalization: Entrepreneurial challenges and opportunities in the developing world. In: Acs, Zoltan et al. (eds.). The role of smes and entrepreneurship in a globalized economy. Expert report no. 34 to Sweden's globalization council. Stockholm, Sweden.

78. World Bank (2005) Doing business in 2005: Removing obstacles to growth, USA.

79. World Bank (2011) Doing business 2011: Economic of west African states -Making a difference for entrepreneurs. Washington, DC: World Bank, USA.

80. Kerr WR, Nanda R (2009) Financing constraints and entrepreneurship. Harvard Business School. Working paper 10-13.

81. World Bank (2014) Doing business 2014: Understanding regulations for small and medium-sized enterprises. Washington, DC: World Bank.

82. Agboli M, Ukaegbu CC (2006) Business environment and entrepreneurial activity in Nigeria: implications for industrial development. J Mod Afr Stud 44: 1-30.

83. Sama H (2011) Challenges and opportunities of Tanzanian smes in adapting supply chain management. Afr J Bus Manag 5: 1266-1276.

84. Unctad (2008) Trade logistics and global value chains. Trade and development board commission on enterprise, business facilitation and development. Geneva.

85. Herrington M, Kelley D (2012) African entrepreneurship: Sub-saharan African regional report. Global Entrepreneurship Monitor. Idrc, South Africa.

86. Edoho Felix M (2015) Guest editorial-Entrepreneurship paradigm and economic renaissance in Africa. Afr J Econ Manag Stud 6: 2-16. 
Citation: Omoruyi EMM, Olamide KS, Gomolemo G, Donath OA (2017) Entrepreneurship and Economic Growth: Does Entrepreneurship Bolster Economic Expansion in Africa?. J Socialomics 6: 219. doi:10.4172/2167-0358.1000219

Page 11 of 11

87. Moyo B (2012) Do power cuts affect productivity? A case study of Nigerian manufacturing firms. Iber 11.

88. Scott A, Darko E, Lemma A, Rud JP (2014) How electricity insecurity affect businesses in low income countries. Overseas development institute report. London: Odi. UK.
89. Arnold J, Mattoo A, Narciso G (2006) Services input and firm productivity in sub-saharan Africa: Evidence from firm-level data, World Bank policy research working paper 4048, South Africa.

90. Akuru UB, Okoro OI (2011) Economic implications of constant power outages on smes in Nigeria. Nigeria. 